\title{
BENLIZÂDE MADRASAH AND ITS PLACE IN OTTOMAN ARCHITECTURE
}

ccording to some written sources, the cultural heritage site, known
as 'the High school (Medrese) of Benlizâde Ahmed Reşid Efendi', is
a medrese (high school) or mektep (primary school) built in Ottoman times, in which a tomb (türbe), fountain (sebil) and graveyard (hazire) were situated at the same time. These buildings may be regarded as being parts of a complex.

Today, the High School of Benlizâde, with its tomb, fountain and graveyard, is situated the quarter of Çarşamba, in the district of Fatih, in the county of Istanbul. The district of Fatih is one of the districts on the European shore of Istanbul. It is bordered by Haliç and Eyüp in the north, the Bosphorus in the east, the district of Zeytinburnu in the west, and the Sea of Marmara in the south.

The history of the district of Fatih is of Istanbul's old, walled 'inner city'. According to the findings of the excavations recently made at the Port of Theodosios in Yenikap1, its history starts from the Neolithic age. After this, a second civilisation, the nomadic Megars from the lands of Greece, settled here in the surroundings of Sarayburnu. The construction of the first walls was in this period ( $657 \mathrm{BC}$ ). This city was founded by Byzas, from whom the name 'Byzantium' derives. ${ }^{1)}$ In $194 \mathrm{AD}$, the Roman emperor Septimus Severus captured the city after a two year siege. Many families moved from Rome to Istanbul during his reign. Istanbul was captured by the Goths in 269, and then by the citizens of Nicomedia in 313. The great Roman emperor, Saint Constantine, then recovered the city from Nicomedia, and in 328 , decided to

1) Çeker (No year: 12). 
defend the city by building fortified walls in the unified continental lands, from the Golden Horn to the Marmara Sea. Finally, in 330, the founding of Istanbul, now known as 'New Rome', was celebrated in a big ceremony. These unified walls, stretching almost from the environs of Samatya to the Golden Horn in Fener during the age of Constantine, were extended to their current length by Emperor Theodosios II (408-450).

The Golden Horn walls, which join the sea and shore walls from the north, were built in the 7th century. In the following century (13th), particularly during the Latin invasion, the walls had to be raised and renovated. Finally, in the year 1453, they needed to be fortified against Turkish attacks. On 29th May 1453, Istanbul fell into the hands of Fatih Sultan Mehmed and became the capital city of the Ottoman Empire.

The Fatih district, which includes the whole of the historical city, was named after the Ottoman emperor Fatih Sultan Mehmed. Following the conquest of Istanbul, the second Sultan, Mehemed Han, built the Fatih mosque on the fourth hillock of Istanbul. Its environs, which were named after Fatih, started to develop, and quickly became an Ottoman Turkish city. Fatih, because of these features, is also known as the 'First Istanbul' or the 'Original Istanbul'.

The founder of the Benlizâde Medrese was Benlizâde Ahmed Reşid Efendi. He achieved fame in the 18th century and was born in the year 1758. He was the son of Mehmed Sidk1 Efendi, one of the scholars in the age of Abdülhamid I. First, he worked as a teacher in several high schools, and then became a judge. After working as a judge in İzmir, he became the Judge of Mekka and then the Judge of Istanbul. Later, he was promoted to 'Kazasker of Anatolia', which means he became the Judge of the Anatolian army, and was then twice appointed 'Kazasker of Rumelia'. In 1822, Benlizâde Ahmed Reşid Efendi was given the office of 'Sheyhulislam', the leader of the religious and justice administration system. He retired in 1823, and lived in his seaside house near Rumelihisarı (Rumelian fortress), where he died in 1834. Although we don't have much information about him, many of his charitable works are well known. ${ }^{2)}$ These include the complex known as Benlizâde Ahmed Reşid Efendi Medrese with its medrese/mektep, tomb, fountain and graveyard, which we shall descibe in this work.

2) Ertuğ (2006: 131). 
Although various sources have given a construction date of 1800 for Benlizâde Ahmet Reşid Efendi Medrese, all we can say for certain is that it was built either at the end of the 18th or beginning of the 19th century (Figs. 1, 2). ${ }^{3}$

Sculptured and unsculptured stone, brick, wood and marble materials, were generally used during the construction of the Benlizâde Medrese. The inner-part of the wall contains rubble with stucco in the Hwarezm style, while the outer walls were built from sculptured stone. The walls of this single-floor building are made from stone, although brick was also used in its open arches, ceilings and cupolas. A wooden gate can be seen in its unique entrance, which has been bricked off and is no longer in use. A semi-circle of brick eaves has been placed above the gate, together with a marble table, but we can no longer read its inscriptions. The walls of the entrance lobby are made of rubble with stucco in the Hwarezm style on the outside. The stucco has partly fallen down. Its windows, which face south, have been covered and closed with brick. The iron bars on the windows show serious signs of corrosion. It has a brick ceiling and stone floor. The facade of the building consists of stone sculpture, and only its walls, which face the garden, are constructed from mixed stone and brick. The entrance lobby and the fountain cover are made of lead, as is the roof of the tomb. The remains of the iron bars, embedded in stone, can be seen on the outside, around the empty window frames.

The architectural features of the Benlizâde Medrese are as follows:

According to some written sources, the cultural heritage site, known as 'the High school (Medrese) of Benlizâde Ahmed Reşid Efendi', is a medrese (high school) or mektep (primary school) built in Ottoman times, in which a tomb (türbe), fountain (sebil) and graveyard (hazire) were situated at the same time. These buildings may be regarded as being parts of a complex (Fig. 3). The complex known as Bu organizasyonlar, which was founded by sultans, housed various communities. Beys, high-ranking officers and people from different religious, social and sometimes economic groups, could all work and be cared for in a system known as 'foundation' (vakif) for many years.

The mektep/medrese buildings of the Benlizâde Ahmed Reşid Efendi Medrese complex no longer exist. Neither do we have any clear evidence as to its architecture. If we examine the period (end of 18th century - beginning of the 19th century), when the Benlizâde High school was built, we see that primary schools were known as 'sibyan mektebi' in the Ottoman Empire, a word

3) Teksarı (2005:39). 
borrowed from the educational institutions of the Seldsuk and other Muslim countries. These schools were the first stage of the Ottoman education system. The so-called 'sibyan mektebi' was the place where 5-6 year-old male and female pupils were educated. In these primary schools, reading and writing, some religious facts and the four basic mathematical skills were taught. The 'sibyan mekteps' were the basis of the medreses. We can separate the 'sibyan mekteps' into the following two groups:

1) 'sibyan mekteps' inside a complex

2) 'sibyan mekteps 'in the quarters.

It is worth noting that the 'sibyan mekteps', located within complexes, are symmetrical with the other buildings in the plan of the complex. The 'sibyan mekteps' inside complexes, have a street entrance as well as a playing field inside. These are always situated on the outer edge of the complexes. This plan came about so that the games and the noise of the children would not disturb the silence in the other parts of the complex, such as the mosque, upper school and library. The 'sibyan mekteps', which have a single building inside quarters, were situated on the edges of crossroads where the streets met. The aim of such planning was for the complex to be almost equidistant to all different parts of the quarter.

In general, sculptured stone and brick was used to build the 'sibyan mekteps' of the Ottoman period. ${ }^{4}$ If we look at the architectural features of 'sibyan mekteps', we can discover that there is little diversity in their plans. Most are rectangular in design and quadrangles rarely appear among them. Because of the rectangular plan, we do not find supporting columns anywhere. In these plans, the walls are the most important units for both enclosure and support. The windows and the gates, as in other ancient buildings, are small in size. Cupola is mostly used in the roof, because of the rectangular shape of the primary schools. The cupola is covered by alaturca antefix and lead. Beyond the cupola, a straight wooden ceiling is in use. These schools have an important common feature, that they are mostly two-storey buildings which are generally simple and have some rooms inside. The schools had gardens outside, which were as extensive as possible. The classrooms, where the students had lessons, were situated higher up, and if possible had some stairs. This shape was popular for one reason: they wanted to protect the children from the wet climate.

4) Yaman (2010: 183). 
In Arabic, a medrese means, "a place where knowledge is taught" or, "a building, where the students sit and have lessons". As in other Muslim countries, this was where secondary or high-level education was taught in the Ottoman education system. The medreses formed part of a foundation and worked under the framework of the directions of the foundation, making use of its organization and financial resources. The medreses in the Islamic world have different aims and services and may be divided into two groups: Universal medreses and Professional medreses. The universal high schools were founded to provide education in the field of Islamic knowledge, together with lessons such as mathematics, physics, geometry, astrology, philosophy, medicine and geometry. The professional medreses were built to impart either Islamic knowledge or only one of the other sciences.

In the Ottoman Empire, the medrese system, in the period before the capture of Istanbul, was a continuation of the Seldsuk system. After the conquest, the medreses started to spread, and in Istanbul, where some churches were turned into medreses, the first medreses were the following: the rooms of the priests in the Zeyrek (ancient Pantokrator) and the church of Hagia Sophia.

The first medrese to be regulated by the state was the one founded by Fatih Sultan Mehmed (Sultan Mehmed the Conqueror), and was named after him. ${ }^{5)}$ Further medreses were founded during the 17th and 18th centuries, when medreses big and small were opened for the public throughout the Empire. $\left.{ }^{6}\right)$ Mixed and curved stones were used in their construction, and following a classical design, the buildings were surrounded a courtyard up until the reforms of the Tanzimat era (age of the Beneficial Reforms). In the 18th century, the number of the teachers became greater and greater, and although it became difficult to find suitable locations, the medreses became more and more important. In Istanbul, there were 173 medreses, guaranteeing education and providing services even in the 19th and 20th centuries. ${ }^{7)}$ There can be little doubt that in this historic peninsula, it was the medreses which allowed culture to flourish and shine.

In the buildings in the complex, known as Benlizâde Ahmed Reşit Efendi Medrese, the tomb, the fountain and parts of the graveyard remain. The tomb, which has a rectangular plan, is built of brick, has one cupola, and its walls are made from curved and uncurved stones. Its general features and painted

\footnotetext{
5) Gül (1997: 58).

6) Kazancigil (2000: 236).

7) İpşirli (2008: 278).
} 
decorations represent the baroque style of the end of the 18th and beginning of the 19th century. ${ }^{8)}$ In the entrance of the tomb, there was a gate with a double wooden wing, although only its halp still exists, and the other has been damaged. We can reach the inner part of the tomb from the gate. By stepping one step above, we enter the tomb which is approximately $6.25 \mathrm{~m} \mathrm{x}$ $6.25 \mathrm{~m}$ in size. The tomb has a rectangular plan, one cupola, made of curved and uncurved stone, and a cupola and brick cover in its roof. The inner side of the windows has been bricked up using brick and stone. Around the inner sides of the windows and the gate, there are frames made of curved stone. The ground is covered with burned soil. Inside the tomb, beside the graves of Ahmet Reşit Efendi and his wife, there is a grave of a relative of theirs. We can see that among the Turkish people, building a tomb is always a symbol of respect and honour. When we investigate Turkish-Islamic art, we can see that large tombs were built for the most important people after their deaths. The Turks, who liked to construct buildings with cupolas, made various different plans of the tombs and rooms, and in this way, they developed the architectural features of the tomb. We can separate the tombs into several groups according to who has been buried there: some tombs were built for emperors, pashas and statesmen, others for religious leaders. ${ }^{9}$

Among tombs built at the same time as the Benlizâde tomb, we can find the following:

The tomb of Koca Ragıp Paşa (1762) in Laleli, the tomb of Mustafa III (1773) in Laleli, the tomb of Şah Sultan'in, sister of Selim III (1800) in Eyüp, the tomb of the mother of Sultan Mahmud Nakşidil II (1817) in Fatih.

Among the buildings of the complex known as Benlizâde Ahmed Reşit Efendi High school, which have survived, we can see the fountain with its rectangular plan and its vault ceiling, dating from the end of the 18th or beginning of the 19th century, as well as the tomb itself. The building was built of marble, stone and brick, and has baroque-styled features in its architecture and decoration. The garden entrance of the sebil was a wooden, onewinged gate, which no longer exists. The main entrance is through a room, which is separated by a wooden window, and situated between this building and the tomb. The dimensions of the building are $6.50 \mathrm{~m} \times 3.85 \mathrm{~m}$, and it has a rectangular shape. There is a unique gate in its eastern front (which is behind), from where the ground becomes higher, with a step from the end of

\footnotetext{
8) Aslanapa (1996: 98).

9) Tanyeli (1994: 311).
} 
the walls of the fountain. The windows of this room have been bricked up. The upper covering of the fountain contains a vault ceiling, made of brick. The walls of the water reservoir were made of curved stone with mortar on their surface. We can reach the upper floor of the reservoir by climbing a step, made of solely of brick. The floor of the fountain is made of natural stone, but has been seriously damaged. The windows of the room still have their original dimensions. The windows of the fountain, which are open to the outside at the corners, have the marble remains of a chesme in their inner walls, and provide evidence that water once flowed through this window, and also that the water came directly from the reservoir, and through the canalization system, to the chesmes.

We can still see the most important feature, which developed fountain architecture and solved the problems of water supply in Istanbul in the past. ${ }^{10}$ During Ottoman times, several emperors tried to bring water from outside the city through large systems and supply the inhabitants by building chesme and sebil gibi watering mechanisms on the quarters and squares. ${ }^{11)}$ The need to provide water was urgent, which is why different people from different groups and occupations built a great many chesmes and sebils as religious foundations.

In the sebils, drinks such as sherbet were given to the travellers who were on road. In general, they were permanent, but sometimes we can see examples made of wood. The water, which came from the sebils, was kept in a closed rooms called a reservoir (hazne). The planning of the fountains depended on their functions and geographical location. As well as sebils with one or more windows, ${ }^{12)}$ which were constructed just to provide water, at the same time we can see historical examples next to tombs, graveyards and 'sibyan mekteps', at the service of a smaller community. We can also notice an increase in the numbers of sebils from the second half of the 16th century, which became more and more widespread during the 17th century. Finally, at the end of the 17th and beginning of the 18th century, there was a further flourishing period in which more sebils were built. ${ }^{13)}$

\footnotetext{
10) Göncüoğlu (2008: 319).

11) Aslanapa (1996: 121).

12) Kilınçer (2007: 20).

13) Ödekan (1994: 481).
} 
The contemporary buildings with a Benlizâde fountain include: Mihrişah Valide Sultan Fountain (1792), Şah Sultan Fountain (1800), Nakşıdil Valide Sultan Fountain (1818), Nusretiye Fountain (1826).

Among the buildings of the complex, which is known as Benlizâde Ahmed Reşit Efendi Medrese, we can find a graveyard (hazire) beside the tomb and the fountain in the plan of the complex. The graveyard is open, surrounded by stonewalls, and situated on the right of the entrance gate, which we can also enter from the garden. This place clearly exists clearly in Pervititch's map, dated 1932. In the archive photographs, which can be obtained from the Archaeological Museums of Istanbul, there are old drawings of two graves from this graveyard. Both have the date 1765 marked on them. During the Ottoman era, it was a very common custom for persons, and their relatives, who had founded buildings such as a mosque, high school, fountain or bath, to be buried next to these buildings, in a graveyard enclosed by stone walls. In this way, the graveyards appeared in the middle of green spaces, and became important historical parts of Istanbul. Those graveyards situated inside the complexes, faced the direction of Kibla (Mekka), and could also contain the remains of travellers. The graves can be seen from outside, so that 'the Fatiha' could be read for every tomb.

According to old photographs, the building complex, known as 'Benlizâde Medresesi', had the characteristic baroque features and decorations of its age. The paintings and baroque features of the tomb can clearly be seen even in the old photographs which exist in the archaeological museums of Istanbul. When we look at the fountain, towards the corner facing north-west where the windows are, we can find marble chesme remains on both inner walls. They are framed in their inner parts (C) and their reverse (C) in a curled manner, and contain a thin and brisk lined oyster motif among the baroque decorations, in accordance with the decorative system in use in the age of the sebil.

In conclusion, we can state that the building complex known as Benlizâde Medresesi, has the same features as other contemporary buildings in its region. Apart from minor alterations, the shemas of the sebil and the tomb could be retained according to their original plan. The building materials however, have become less stable over the years, and the construction has also become weak. The buildings need thorough renovation and the destruction of the original rooms needs to be stopped (Figs. 4, 5). 


\section{BIBLIOGRAPHY}

Aksoy (1967) = Ȯzgönül Aksoy, Osmanl Devri Istanbul Slbyan Mektepleri Üzerine Bir Inceleme (unpublished doctorate thesis at the, I.T.U Faculty of Architecture), Istanbul 1967.

Arpat (2006) = Atilla Arpat, Dini Mimaride Gizli Tasarım Yöntemleri, Birsen Pub. Istanbul 2006.

Aslanpa (1986) = Oktay Aslanpa, Osmanlı Devri Mimarisi, İnkılap Pub., Istanbul 1986.

Aslanpa (1993) = Oktay Aslanpa, Türk Sanatı, Remzi Pub., Istanbul 1993.

Aslanpa (1996) = Oktay Aslanpa, Osmanlı Mimarisi, Türkiye İş Bankası Pub., Istanbul 1996.

Aslanapa (2008) = Oktay Aslanpa, "Roma ve Osmanlı İmparatorluğunda Su Mimarisi", Uluslararası Tarihi Yarımada Sempozyumu Teblĭ̆ler Kitabl, 3. Istanbul, 2008: 28-30.

Aynur (1998) = Hatice Aynur, 1998, "18.yy Istanbul Çeşmeleri”, 18.Yüzyllda Osmanlı Kültür Ortamı Sempozyum Bildirileri 20-21 Mart 1997, Istanbul, 1998: 33-42.

Ayverdi (1978) = Ekrem Hakkı Ayverdi, 19.Asırda Istanbul Haritasl, Istanbul Fetih Cemiyeti Pub., 1978, Istanbul.

Bulut (2010) = Nazlı̈ül Bulut, Fatih'in Kayıp Çeşmeleri, IBB Kudeb pub., Istanbul 2010. Çeker $($ no year) $=$ Alper Çeker, Fatih Rehberi, Kültür A.Ş., Istanbul.

Dağdelen (2007) = İrfan Dağdelen, Alman Mavileri: 1913-1914 I.Dünya Savaşı Öncesi Istanbul Haritalarl I-II-III, Istanbul 2007.

Egemen (1993) = Affan Egemen, Istanbul'un Çeşme ve Sebilleri, Istanbul 1993.

Ertuğ (2006) = Necdet Ertuğ, Istanbul Tarihi Çeşmeler Külliyatı I-II-III, ISKI, Istanbul 2006. Göncüoğlu (2008) = Faruk Göncüoğlu, "Fatih'i Tanımak", Fatih Sempozyumları I-II-III Bildiri Kitabl, Fatih Municipality, Istanbul, 2008: 318-321.

Göncüoğlu (2011) = Süleyman F. Göncüoğlu, Istanbul’un Kitabı Fatih, Fatih Municipality Pub, 2011, Istanbul.

Gül (1997) = Ahmet Gül, Osmanlı Medreselerinde Ĕgitim-Öğretim ve Bunların Arasında Dârül-Hadislerin Yeri, TTK., Ankara 1997.

İnalcık-Günsel (2004) = Halil İnalcık-Günsel Renda, Osmanlı Uygarlığı I-II, pub. by Ministry of Culture, Ankara 2004.

İpşirli (2008) = Mehmet İpşirli, "Beyazıt ve Fatih Semtlerinde (19. ve 20.yy) Muhitler", Uluslararası Tarihi Yarımada Sempozyumu Tebliğler Kitabı, 3, Istanbul, 2008: 278-280. facques Pervititch Sigorta Haritalarında Istanbul, Tarih Vakfi-Axa Oyak, Istanbul 2000. Karapilehvarian (2000) = Nuran Karapilehvarian, Osmanlı Başkenti Istanbul'da Çeşmeler, Yem Pub., Istanbul 2000.

Kazancıgil (2000) = Aykut Kazancıgil, Osmanlılarda Bilim ve Teknoloji, Ufuk Kitapları, Istanbul 2000 .

Kılınçer (2007) = Gülşen Kılınçer, Kaybolan Çeşmeler, Istanbul 2007.

Koçu (1958-74) = Reşat Ekrem Koçu, "Benlizade Mektebi", in: Istanbul Ansiklopedisi V. 5, Istanbul, 1958-74: 2512-2552.

Laqueur (1997) = Hans-Peter Laqueur, Hüve'l-Baki Istanbul'da Osmanll Mezarliklarl ve Mezar Taşlarl, Istanbul: Tarih Vakfı Yurt Pub., 1997.

Lewis (2006) = Raphaela Lewis, Osmanlı'da Günlük Yaşam, Ankara: Adapa Pub. 2006,. 
Süreyya (1996) = Mehmed Süreyya, "Sicill-i Osmanî”, Dünden Bugüne Istanbul Ansiklopedisi, V.6, Tarih Vakfı, Istanbul 1996.

Ödekan (1994) = Ayla Ödekan, "Sebiller", Dünden Bugüne Istanbul Ansiklopedisi, V.4, Tarih Vakfi, Istanbul 1994: 481-482.

Özel (2009) = Ahmet Murat Ȯzel, Geçmişten Günümüze Istanbul'da Suyun Yönetimi, Istanbul 2009.

Sakaoğlu (1994) = Necdet Sakaoğlu, "Sıbyan Mektepleri”, Dünden Bugüne Istanbul Ansiklopedisi, Tarih Vakfi, Istanbul 1994: 546-547.

Şahin (2009) = Soner Şahin, Değişim Sürecinde Osmanlı Mimarlı̆̆ı III.Ahmet ve I.Mahmud Dönemi(1703-1754), (unpublished doctorate thesis at the, I.T.U Institute faculty of science), 2009 Istanbul.

Tanışık (1943) = İbrahim Hilmi Tanışık, Istanbul Çeşmeleri, Istanbul 1943.

Tanyeli (1994) = Gülsün Tanyeli, “Türbeler”, Dünden Bugüne Istanbul Ansiklopedisi, V.7, Tarih Vakfı, Istanbul, 1994: 310-312.

Teksarı (2005) = Serhat Teksarı, Istanbul Türbeleri, Gül Pup., Istanbul 2005.

Tibet (1994) = Aksel Tibet , "Hazireler", Dünden Bugüne Istanbul Ansiklopedisi, V.4,

Tarih Vakfl, Istanbul 1994: 38-39.

Üstün (2000) = Ayşe Üstün, Osmanlı Arşivindeki Istanbul Cami ve Türbelerinin Tamirleri Ille İlgili Belgeler, (unpublished doctorate thesis at the Dokuz Eylül Uni. Institute of Social Sciences), İzmir 2000.

Yaman (2010) = Ayşe Peyman Yaman, Osmanlı da Mekteplerin Ortaya Çıkışı ve

Gelişmeleri (unpublished doctorate thesis at the Marmara Uni. Institute of Social Sciences), Istanbul 2010.

Yllmaz (2009) = Şadiye Yılmaz, Osmanlıdan Cumhuriyete Sibyan Mekteplerinde

Yenilik ve Gelişmeler (unpublished postgraduate thesis at the Selçuk University Institute of Social Sciences Department), Konya 2009. 


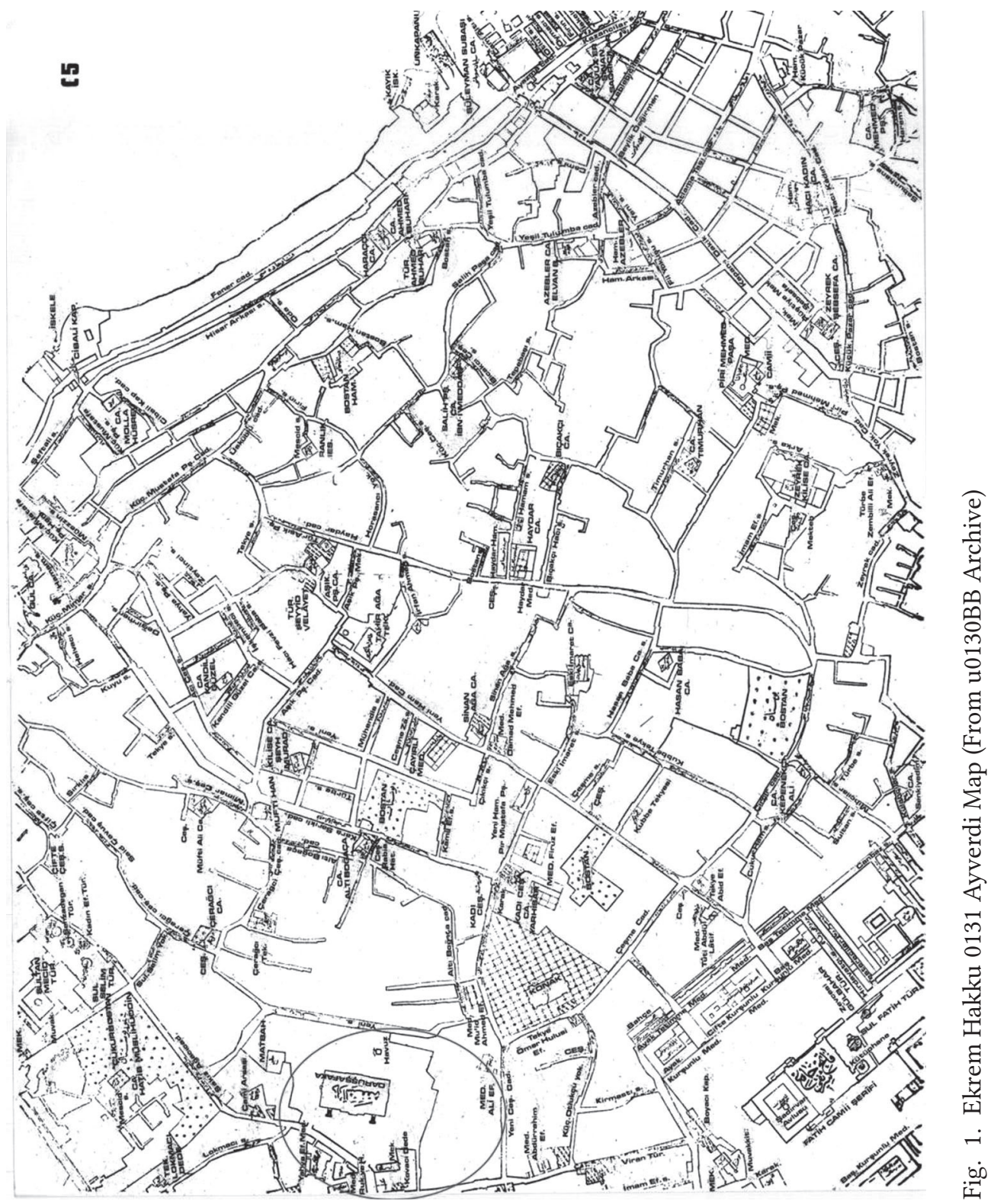




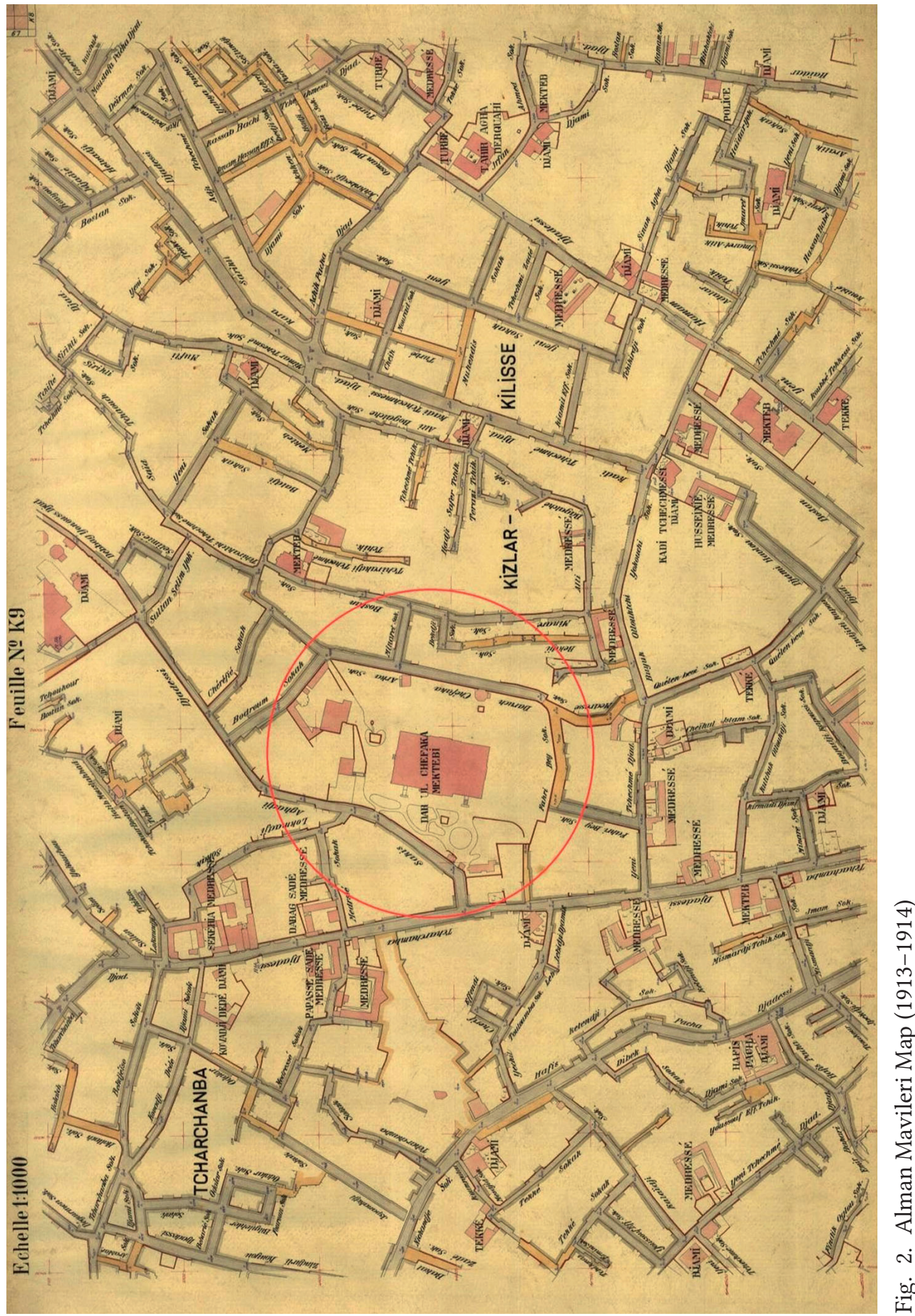




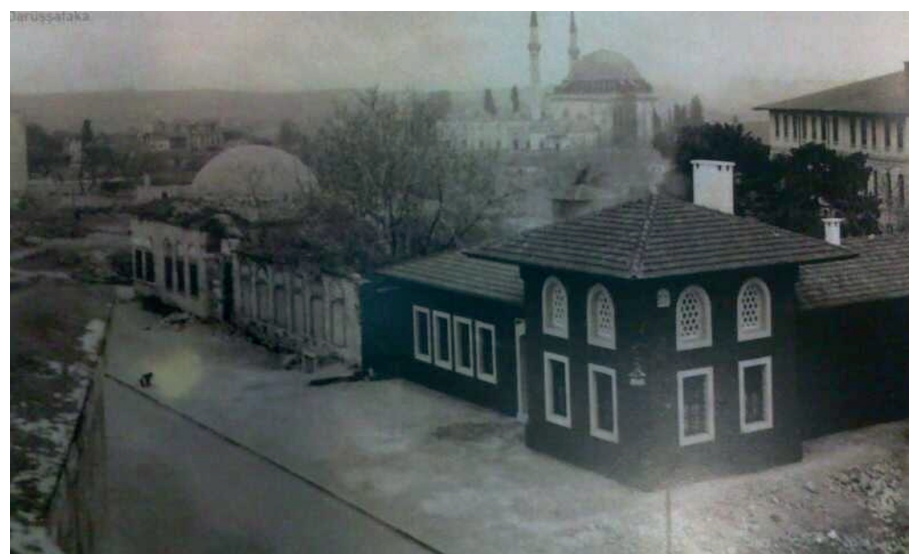

Fig. 3. Benlizade Madrasah (before 1948)

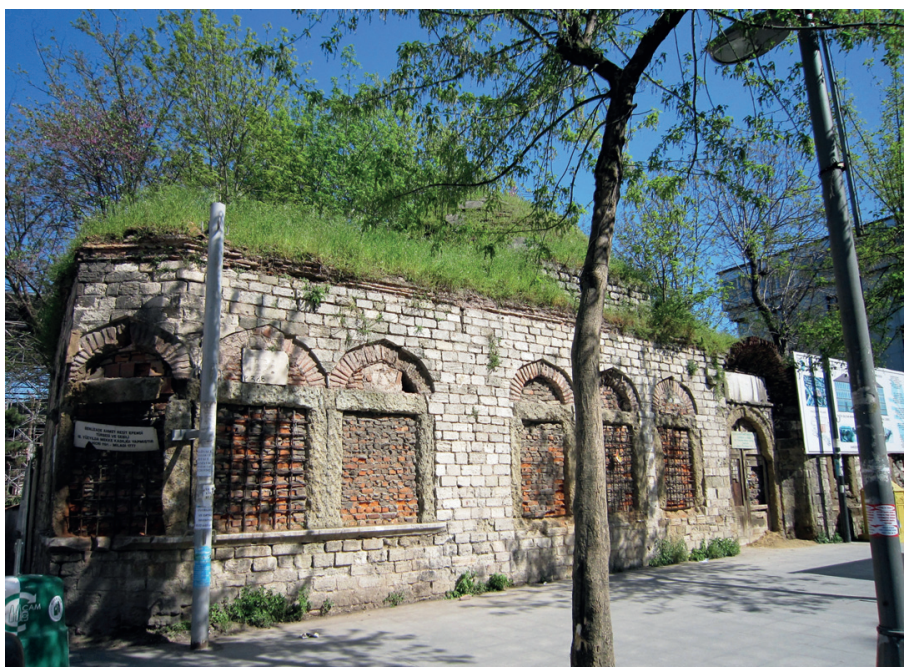

Fig. 4. Benlizade Madrasah (2014)

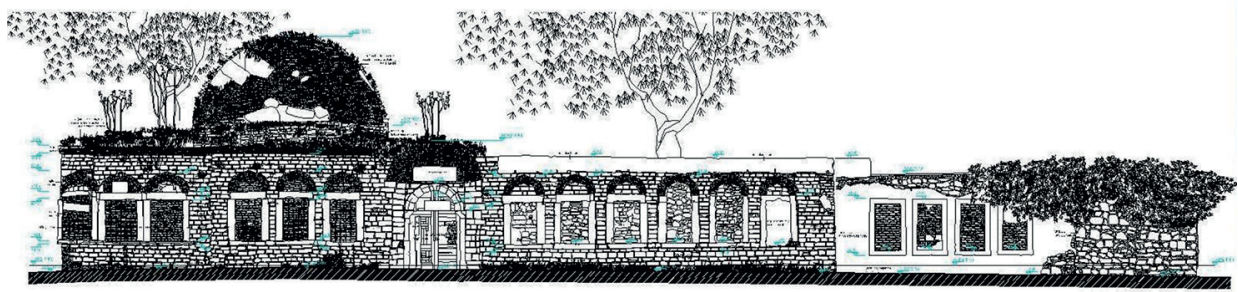

BAT (YN) CEPHES:

Fig. 5. Benlizade Madrasah Breakthrough Plan (EMR Architecture) 